Journal of Urban and Regional Analysis, vol. VII, 2, 2015, p. $161-176$

\title{
INDIVIDUALISATION OF DEPRIVED AREAS IN ROMANIA'S SOUTH WEST REGION
}

\author{
Radu-Matei COCHECI \\ "Simion Mehedinți" Doctoral School, Faculty of Geography, \\ University of Bucharest, Romania
}

\begin{abstract}
Measuring territorial disparities is the first step in studies aiming to improve territorial cohesion. As intraregional disparities are often higher than inter-regional ones, an analysis of development at local level is needed in order to define areas of intervention for specific targeted policies. The aim of this study is to individualise deprived areas in Romania's South West region through the use of the Principal Component Analysis run on 15 social, economic, demographic and physical indicators defined at local level (LAU 2 units). By computing a global index of deprived areas, 13 areas were individualised at regional level, with the results being compared with other studies on deprived areas (Romania's poverty map, Social Development Index and Less-favoured areas). The final output showcased the differences in defining deprived areas according to the used methodology, with a need to standardise such methods for policy targeting in the future while also considering environmental quality factors.
\end{abstract}

Key Words: territorial disparities, Principal Component Analysis, territorial cohesion, environmental quality, less-favoured areas.

\section{Introduction}

The European Union's territory is characterized by geographical discontinuities (Faludi 2004), with the geographical space being by excellence heterogeneous (Ancuta 2010). Giving priority to the support of regions whose development is lagging behind (CEC 2003) and ensuring that community policies' impacts fit into a spatial framework (Faludi 2004), represent determinants for the emergence of another concept in the EU policy - territorial cohesion. Considered to be a way of spatializing the European Social Model (Davoudi 2005), the concept of territorial cohesion focused on interconnecting economic effectiveness, social cohesion and ecological balance, thus putting sustainable development at the heart of policy design (CEC 2008).

On the one hand, territorial cohesion can be seen as a way of adding a spatial justice dimension to the spatial policy at European level (Davoudi 2005), underlining the importance of spatial concentration for overcoming differences in density, connecting territories for overcoming distances and cooperation for overcoming divisions (CEC 2008). On the other hand, when discussing uneven development across regions we can use the concept of regional competitiveness (Huggins et al. 2014). The geographical variance of competitiveness, stemmed from the differential development of regions depending on drivers of growth (Audretsch and Keilbach apud Huggins et al. 2014), can be measured according to the characteristics of the regional business environments (Huggins et al. 2014). Consequently, while territorial cohesion has strong social and spatial justice components, measuring the variance of competitiveness across geographical space is mostly based on economic factors.

As such, territorial cohesion can be viewed as the attempt to reduce (often economic) disparities between different spatial categories (Niebuhr and Stiller 2003). Including other concepts such as territory, development or spatial equity (Ancuța 2010), territorial disparities are considered to be a fundamental characteristic of a society's spatiality (Benedek and Kurko 
2011). Their analysis become a first obligatory step for studies on the way to improve territorial cohesion (Ancuta 2010), with a multi-scalar approach being encouraged due to the fact that intraregional differences are often much higher than inter-regional disparities (Goschin et al. 2008, lanos et al. 2010). Consequently, some argue that territorial cohesion should be an issue of policy aimed at national or regional levels, and not at EU level (Niebuhr and Stiller 2003), while others even consider that cohesion at continental level cannot be achieved if disparities in revenue at local level are not reduced (lanoș et al. 2010).

Unequal spatial distribution can determine specific paths of territorial development (Benedek and Kurko 2011), often determined by path-dependent economic factors which proved to be difficult to reverse (Salvati and Zitti 2011). Other factors also become important when assessing territorial disparities: countries with a better quality of government often register lower levels of spatial inequality (Ezcurra and Rodríguez-Pose 2014), while growth gaps can also be explained by the geographical location and transport facilities (Démurger 2001).

The objective of this paper is to individualise the deprived areas - territories defined at inter-local level, with social, economic and infrastructure issues which impede development - in Romania's South West region and to verify the obtained results with other previous attempts in the Romanian literature to determine disadvantaged areas.

At territorial level, disparities between different areas can be identified and be appreciated quantitatively through the use of socio-economic indicators (Medeiros 2012). In the wake of the challenge posed by social and economic cohesion at territorial level, the intervention in such disadvantaged areas becomes of utmost importance, as the lack of measures can lead to real problems in territorial management (lanos et al. 2010). The identification of this type of areas requires the detection of development discontinuities, as well as the analysis of territorial development processes at different scales (lanoș et al. 2009).

Although the study of territorial disparities is relatively new in the Romanian literature (Ancuța 2010), there is a special attention given to the different methods of defining disadvantaged areas through the use of various criteria. For example, a profoundly disadvantaged area can be defined as an area characterized by the spatial contiguity of minimum 5 LAU 2 units, where the average of the global development indicator is $25 \%$ under the global indicator of the disadvantaged area in which it is contained or it is $75 \%$ under the regional level average (lanoș and Heller 2006), with 8 indicators being used for the individualisation of these areas. Other studies seek to identify profoundly disadvantaged areas through indicators referring to quality of life, development potential or economy, with the identified areas being the product of both historical evolution and accessibility levels (lanoș et al. 2010). Measuring territorial disparities at a lower spatial scale can also be done in a cross-border context (Nagy 2014), with three components - demographical, quality of life and economic indicators - being used in this case in a factorial analysis. In other cases, a global index is calculated based on standardised values of elementary variables, also with three similar categories of variables being considered: social, economic and life standard indicators (Ancuța 2010).

Other studies prefer to measure disparities at NUTS 3 (county) or NUTS 2 (region) level, with the focus on either economic aspects (Benedek and Kurko 2011), rural development issues (Dachin 2008) or complex approaches which seek the construction of a relevant index (lanos et al. 2013). The results of these studies are often in the form of typologies: a typology of multi-criteria disparities at county level (Goschin et al. 2008) or a typology of advantaged and disadvantaged areas defined at local level (Ancuța 2010).

Besides the above mentioned studies which seek to identify disadvantaged areas, there is an important research focused on defining a hierarchy of Romanian communes according to their development (Commune Development Index - Sandu et al. 2009), also on the basis of simple 
economic and social indicators, which are then standardised and aggregated into indices. Poverty maps also fall into this category: they present a geographic profile of welfare, underlining the areas with a great concentration of poverty, where resources need to be allocated (Pop 2004). Welfare and social exclusion indicators support the realization of these maps.

Nevertheless, beyond similar concepts found in literature, the concept of disadvantaged areas can be associated with several policies at EU and national level. The European Commission defines the less-favoured area through the territories where agricultural activities are impeded by natural factors such as climate, terrain slope or soil fertility. An area can thus be considered less-favoured if agriculture is endangered by certain economic or environmental issues (Giesecke et al. 2010). The fragility of agricultural activities, limited access and population decline are amongst the factors used to define less-favoured areas (Ruben et al. 2007), with the lower agricultural potential of the areas being explained not only by natural features like soil or climate, but also by their limited infrastructure or poor access to markets (Fan and Hazell 2000).

The less-favoured area measure is one of the oldest measures (since 1975) with a territorial projection in the EU's Common Agricultural Policy (Dwyer et al. 2007), as part of its second pillar. However, poor people which live in these environments often face poverty and resource degradation issues (Ruben and Pender 2004). Consequently, the second pillar of CAP is trying to support these rural regions that are lagging behind through different measures (Shucksmith et al. 2009) aimed at preventing agricultural land abandonment (Giesecke et al. 2010) caused by demographic or economic factors (IEEP 2006). However, the CAP is currently considered to be insufficient in new member states facing structural problems in their rural areas (Gorton et al. 2009).

The European Commission defines 4 categories of less-favoured areas which can access funds in the second pillar of PAC (IEEP 2006): mountain areas, areas affected by specific handicaps, areas with environmental restrictions and other less-favoured areas. In Romania, the communes that are declared as less-favoured areas are included in the National Rural Development Programme 2007-2013 (MARD 2010). However, the criteria used to define these areas are strongly connected to their agricultural potential, thus ignoring other social and economic problems which a territory can have.

At national level, between 1996 and 2005, some economic and social policies were promoted, aimed at stopping the decline of the areas affected by industrial restructuring or massive layoffs and at attracting investments by offering financial incentives. These areas, called deprived areas, are defined in the Romanian Law (Governmental Order no. 24/1998, Law no. 20/1999) as geographical areas which face one of the following conditions:

- they had mono-industrial productive structures (which included over $50 \%$ of the total employees in the area);

- they were mining areas with over $25 \%$ dismissed personnel;

- collective layoffs affected over $25 \%$ of the employees in that area, following the restructuring of economic agents;

- the unemployment rate surpassed by $30 \%$ the average at national level;

- they were isolated areas with poorly developed infrastructure.

Nevertheless, the law suffered numerous changes (Governmental Order nr. 525/1999, Law no. $507 / 2004$ ), the only remaining criteria being those related to the unemployment rate and the degree of isolation. Between 1998 and 2001, 35 deprived areas were declared in Romania, mostly located in mining and industrial areas. These areas are not active anymore, as the financial incentives were only offered for ten years. 
Consequently, the concept of deprived area does not have an up to date legislative framework, as it was initially defined in a different socio-economic context (the end of the 90s). The lack of legislative framework is an opportunity to try to redefine the criteria on the basis of which these deprived areas are declared, also taking into account the methodological aspects employed in other reviewed studies.

The following section seeks to shortly describe the main elements which have influenced the deepening of territorial disparities in Romania's South West Region. I considered that for a regional analysis of territorial disparities, the LAU 2 level is the better option as it enables the detection of contiguous territorial units - deprived areas - which can then become areas of intervention for specific targeted policies.

\section{Study area: Romania's South West Region}

The territory chosen for this analysis is the Romania's South-West Region (Oltenia), one of the poorest regions in the country according to recent economic indicators (it ranked 7th out of 8 regions for direct foreign investments in 2013 - National Bank of Romania data - and for GDP/ capita in 2013 - Eurostat data). As far as economic activities are concerned, Oltenia is the most important region for the Romania's energy industry, fact which is highlighted by the existence of hydroelectric and power plants with the highest capacity in the country (Erdeli and Cucu 2007). However, the energy industry along with the extraction of lignite in the MotruRovinari or Alunu-Berbeşti areas, have an increased pressure on the region's environmental quality. Furthermore, the industrial decline which characterized Romania after 1990 has affected an important number of cities in the region, especially the ones which have relied on a single industrial activity (Dumitrescu 2008, Constantinescu 2012).

The region consists of five counties (Mehedinți, Gorj, Dolj, Vâlcea, Olt) and 448 base territorial administrative units (LAU 2 units). Of the 40 cities located in the South West Region, only the five county capitals and the municipality of Caracal (Olt) exceed 20000 inhabitants. Hence, $85 \%$ of the region's cities can be considered small towns, which are known to have a reduced resilience as they face economic decline (ESPON 2006). Moreover, 16 of the 40 cities (40\%) are the result of forced urbanisation during the communist area (rural communities which have been declared cities between 1945 and 1989), while 8 communes have been declared cities after 1990 (Săgeată 2011). The over-urbanization of the communist area is strongly sustained by the fact that centrally planned industrialization was directly related to urbanization (Harris 1970 apud Constantinescu 2012). The structural problems of the region's urban system are also motivated by the fact that six of the region's cities (Motru, Rovinari, Ticleni, Bumbeşti Jiu, Balş, Brezoi) are considered to be mono-industrial (Dumitrescu 2008). Of the three deprived areas declared in the region (Governmental Order no. 24/1998), two contain such monoindustrial cities (Schela deprived area - the city of Bumbeşti Jiu; Motru-Rovinari deprived area - the cities of Motru and Rovinari). Public services are also lagging behind compared to other regions, as underlined by the comparison with the South Muntenia region regarding health services (Costaiche and Niculae 2014).

As far as rural areas are concerned, after the fall of the communism and the fragmentation of large-scale collective farms, the agricultural system can be characterized by degradation and social disintegration (Fraser and Stringer 2009). It is the case especially in the counties of Dolj and Mehedinți, depending greatly on agriculture and affected by the destruction of the irrigation systems after 1990 and by population migration (Mazilu and Bădiță 2014). Consequently, although agriculture is an important resource for the region, with over 1 million hectares of land available for cultivation, the region is characterized by inferior productivity due to insufficient technical equipment, small-scale agricultural enterprises and underdeveloped irrigation systems (Necula and Necula 2012). The demographic vulnerability of the region, especially in its rural areas (Mazilu and Bădiță 2014), along with aridization problems in the southern area 
with high agricultural potential (Prăvălie et al. 2014) and uncorrelated actions regarding land use changes (Petrișor 2015), contribute to a low level of capitalization related to the region's agricultural potential.

As explained above, Romania's South West Oltenia region presents notable territorial disparities when compared to the more developed regions in the country. However, a thorough analysis of the situation in LAU 2 units, as the one proposed in this article, could give a more detailed insight on the structural problems existing at local and inter-local level.

\section{Methodology}

The first step of the study was to identify the deprived areas in the Romania's South West Region according to other previous studies or legal provisions. Consequently, four maps were realized using GIS software that showcased, at regional level, the LAU 2 units falling into different deprived area categories (Table 1).

Previous studies regarding the identification of deprived areas

Table 1

\begin{tabular}{|c|l|l|}
\hline No. & \multicolumn{1}{|c|}{ Type of area } & \multicolumn{1}{c|}{ Study / legal provision } \\
\hline 1 & Deprived area & Governmental Order no. 525/1999, Law no. 507/2004 \\
\hline 2 & Deprived communes & Poverty map (Pop 2004) \\
\hline 3 & $\begin{array}{l}\text { Under-developed com- } \\
\text { munes and towns }\end{array}$ & $\begin{array}{l}\text { Settlement Social Development Index under 30 - communes } \\
- \text { or under 65 - towns (Sandu 2011) }\end{array}$ \\
\hline 4 & Less-favoured areas & CAP - National Plan for Rural Development 2007-2013 \\
\hline
\end{tabular}

The second step was the calculation of 15 economic, demographic, social and physical indicators (Table 2) for all 448 LAU 2 units in the region, using data from the Ministry of Regional Development and Public Administration. Descriptive statistics and all possible paired correlations were computed using SPSS 20 in order to supress the variables whose variance could also be closely explained by other variables as well. After having a final list of indicators, a Monte Carlo Parallel Analysis (condition Eigenvalue $>1$ ) was run in order to identify the number of components which need to be taken into account for a correct Principal Component Analysis.

The Principal Component Analysis (PCA) showcased the indicators which explain the most part of the variation of all indicators taken into consideration in the analysis, with the method relying on the assumption that the variation of the level of development is explained not only by the variation of factors specific to each variable, but also by common factors (lanoș et al. 2013). The method was also used in other studies focused on measuring territorial disparities at LAU 2 unit level (Nagy 2014).

For each PCA component, an index from 1 to 5 was computed for each LAU 2 unit based on quantile statistical breaks, where 1 signified that a LAU 2 unit was in the lower $20 \%$ of that indicator's variation at regional level, while 5 signified that a LAU 2 unit was in the upper $20 \%$. Eventually, based on weights given to each index according to the cumulative variability percent explained (extracted from the PCA), a global index of deprived areas was computed at LAU 2 unit level. Consequently, the deprived areas were identified at regional level, according to the following conditions:

- the global index of deprived areas for each LAU 2 unit is in the lower $40 \%$ of the index's variation;

- there are minimum 4 contiguous LAU 2 units which register such values; 
Indicators used for the deprived areas analysis (LAU 2 level)

\begin{tabular}{|c|c|c|c|}
\hline No. & Indicator & Year & $\begin{array}{l}\text { Type of } \\
\text { indicator }\end{array}$ \\
\hline 1 & Income per inhabitant & 2012 & \multirow{5}{*}{ Economic } \\
\hline 2 & Total turnover & 2009 & \\
\hline 3 & $\begin{array}{l}\text { Employment rate (percent of employees from total } \\
\text { population) }\end{array}$ & 2011 & \\
\hline 4 & Income dynamics (\%) & $2005-2012$ & \\
\hline 5 & $\begin{array}{l}\text { Accommodation units } \\
(-1-\text { no units; } 0 \text { - guest houses; } 1 \text { - hotels) }\end{array}$ & 2012 & \\
\hline 6 & Emigration rate $(\% \circ)$ & 2008 & \multirow{4}{*}{ Demographic } \\
\hline 7 & Dynamics in the number of housing units (\%) & $2005-2011$ & \\
\hline 8 & Population dynamics (\%) & $2005-2011$ & \\
\hline 9 & Inhabitants/household & 2011 & \\
\hline 10 & Number of teachers (\%o) & 2011 & \multirow{4}{*}{ Social } \\
\hline 11 & Number of doctors (\%o) & 2011 & \\
\hline 12 & $\begin{array}{l}\text { Health services provided } \\
(-1 \text { - no service; } 0 \text { - dispensary; } 1 \text { - hospital) }\end{array}$ & 2011 & \\
\hline 13 & $\begin{array}{l}\text { Educational services provided } \\
(-1-\text { school only; } 0 \text { - professional school; } 1 \text { - high- } \\
\text { school) }\end{array}$ & 2011 & \\
\hline 14 & $\begin{array}{l}\text { Amount of gas distributed to the population } \\
\text { (cubic metres/inhabitant) }\end{array}$ & 2011 & \multirow[t]{2}{*}{ Physical } \\
\hline 15 & $\begin{array}{l}\text { Amount of water distributed to the population } \\
\text { (cubic metres/inhabitant) }\end{array}$ & 2011 & \\
\hline
\end{tabular}

- if a single LAU 2 unit is in the upper $60 \%$ of the index's variation, but it is surrounded by LAU 2 units in the lower $40 \%$, it will also be included inside the deprived areas for contiguity reasons.

In the end, the deprived areas individualised in Romania's South West Region were compared to the results of previous studies in order to verify the accuracy of our findings.

\section{Results and discussions}

Romania's South West Region contains three deprived areas, according to the provisions of the Romanian Law in 1999 (Fig. 1). The three areas (Albeni, Motru-Rovinari, Schela) are all located within Gorj county and have been declared deprived areas mainly due to the decline of the large-scale mining industry (coal).

As far as the study regarding Romania's poverty map is concerned (Fig. 2), most of the identified deprived communes were located in the county of Mehedinți (especially in the northern and eastern part), with others scattered in the counties of Dolj and Vâlcea and with the counties of Gorj and Olt accounting for only one commune each. Nevertheless, a more recent analysis regarding a Social Development Index for all settlements, computed on both urban and rural areas, underlines the problems of the region's urban system: over a quarter of the region's cities (11 out of 40) are considered to be under-developed. As far as rural areas are concerned, the issues of poverty described by Pop in 2004 do not seem to have been solved in 2011, as the same areas in Mehedinți county appear to be under-developed. Moreover, the 
western part of Dolj county represents a concentration of under-developed communes as well, along with other parts in the north and south-east of Olt county or in the central part of Vâlcea county.

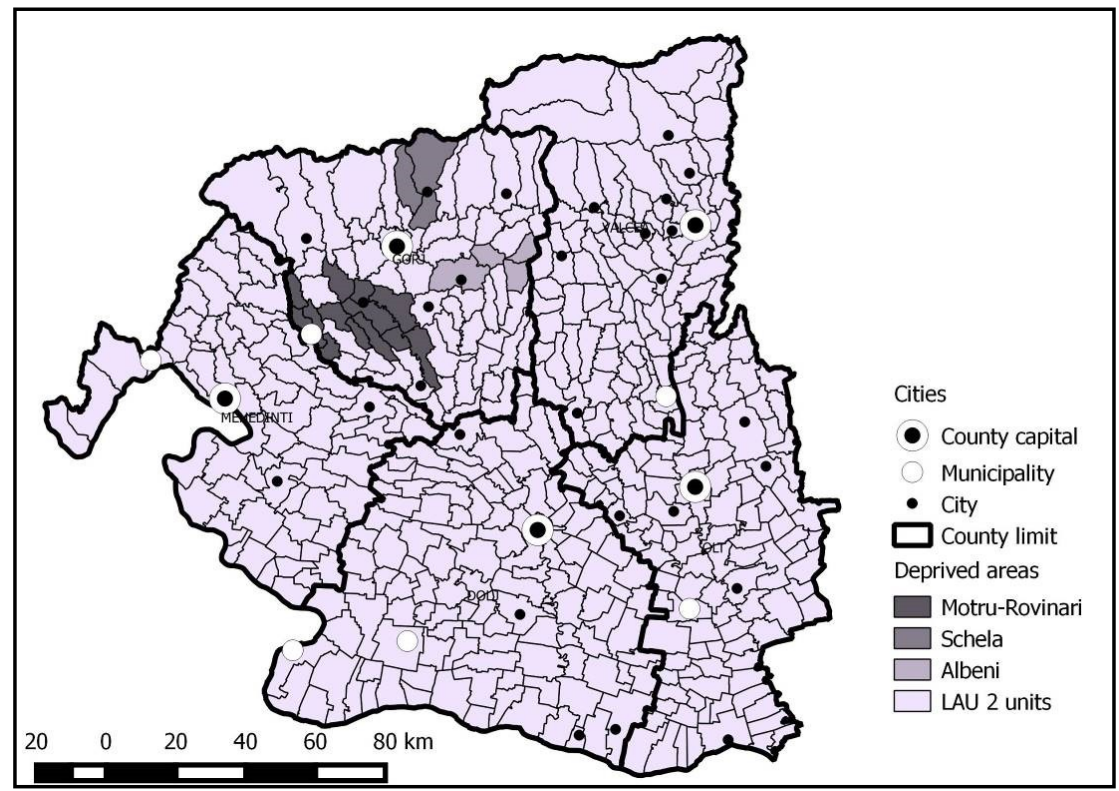

Fig. 1 - Deprived areas according to Romanian Law Source: Governmental Order no. 525/1999 (processed by the author)

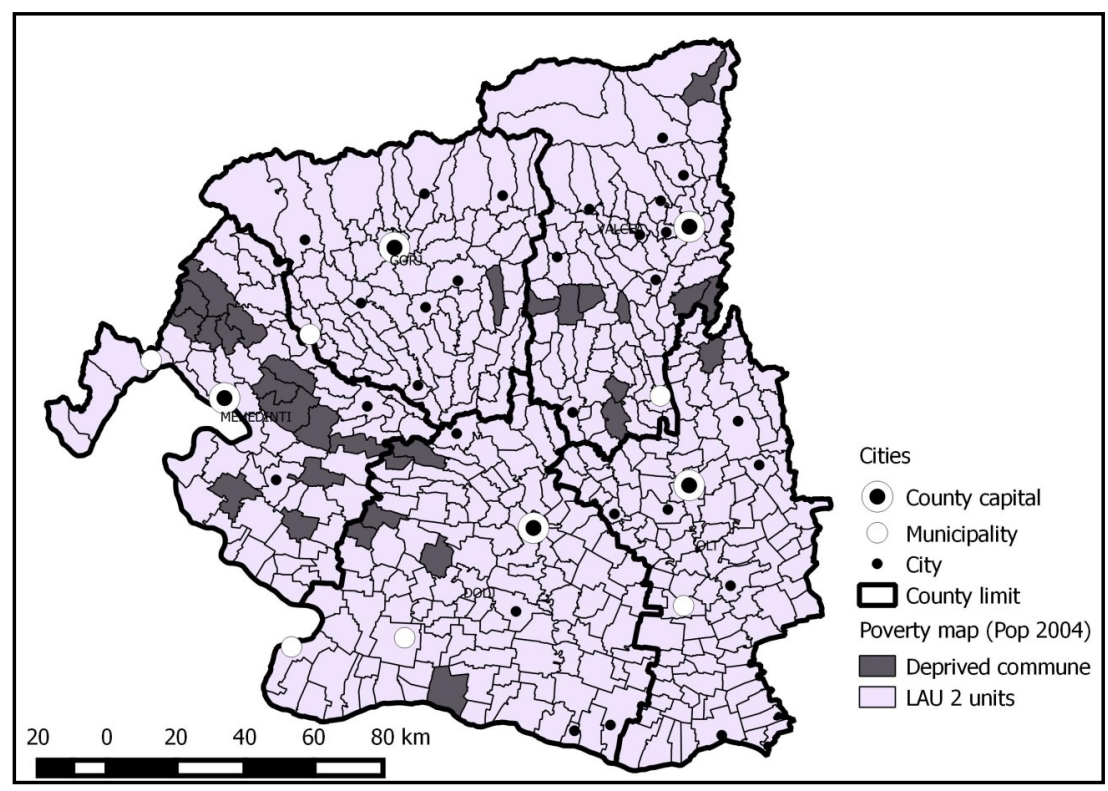

Fig. 2 - Deprived communes

Source: Pop 2004 (processed by the author) 
An analysis of the less-favoured areas as they appear in the Romania's National Rural Development Programme 2007-2013 (Fig. 4) reveals a concentration of mountain areas in the north part of the region, but also some areas with specific handicaps concentrated in the south of the region (along the Danube and the Jiu valley), in the Motru-Rovinari lignite basin (Gorj county) and in the western part of Dolj county.

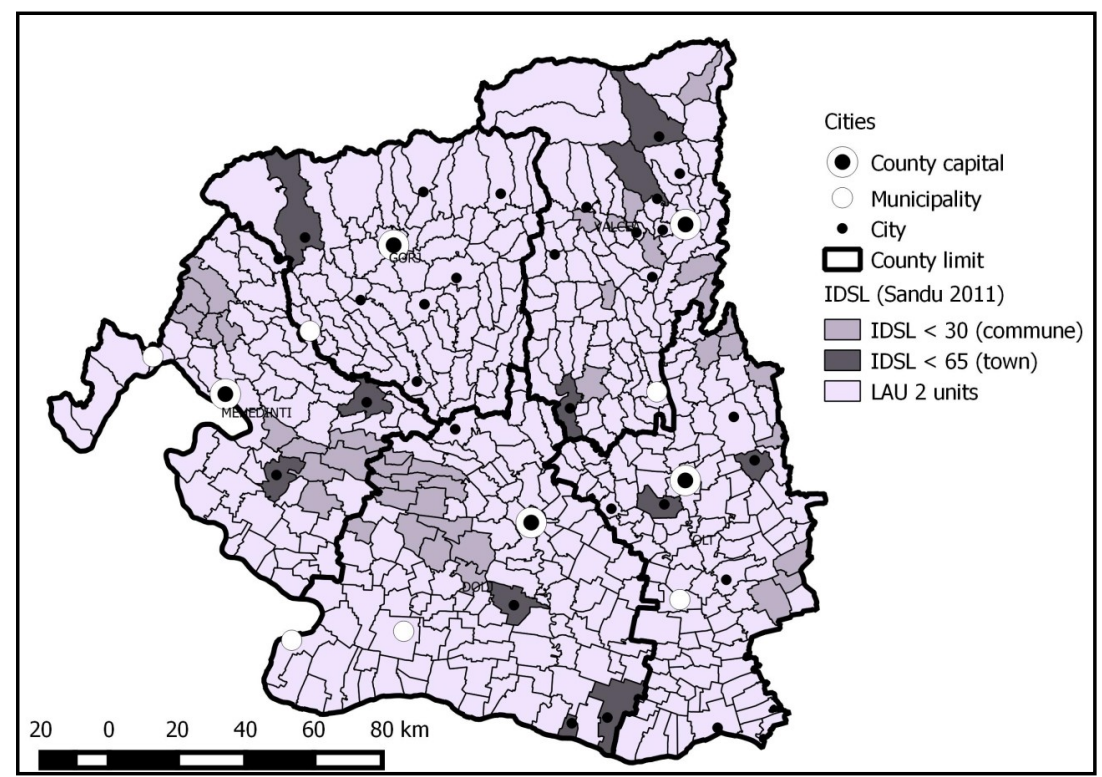

Fig. 3 - Settlement Social Development Index (IDSL) Source: Sandu 2011 (processed by the author)

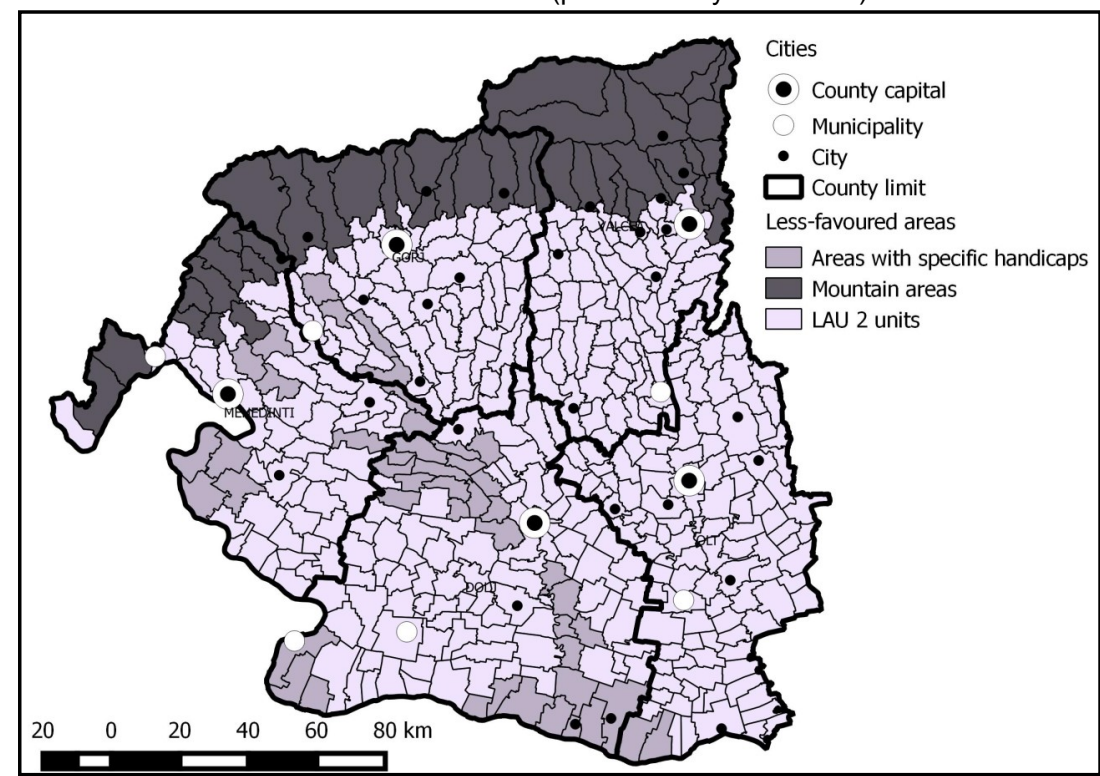

Fig. 4 - Less-favoured areas in Romania's South West Region

Source: National Programme for Rural Development 2007-2013 (processed by the author) 
Each of the above methods for determining areas which are lagging behind focuses on different components for the individualisation of deprived areas: unemployment rate (mostly) in the case of the deprived areas declared by the Romanian law; social exclusion and poverty indicators for the poverty map of Romania (Pop 2004); aggregated social and economic indicators for the Social Development Index (Sandu 2011); and factors related to agricultural potential for the less-favoured areas.

As a result, I tried to individualise the deprived areas in the Romania's South West region through the use of the PCA statistical method, applied on 15 pre-selected indicators (variables). The descriptive statistical analysis and paired correlation results determined me to eliminate three of the indicators (total turnover, income dynamics and health services provided), which had a correlation of above 0.95 with the income per capita variable.

The Monte Carlo Parallel Analysis (Eigenvalue > 1) determined the number of components to be considered in the PCA to be four. Consequently, the result of the Principal Component Analysis was that four components from the 12 indicators analysed accounted for a cumulative $55.63 \%$ of the entire variability of the dataset. These four components are detailed in Table 3 , along with the weight of each component in the global index of deprived areas.

Table 3

Indicators used for the deprived areas analysis (LAU 2 level)

\begin{tabular}{|c|l|c|c|c|}
\hline No. & \multicolumn{1}{|c|}{ Indicator } & Year & $\begin{array}{c}\text { Type of } \\
\text { indicator }\end{array}$ & Weight \\
\hline 1 & $\begin{array}{l}\text { Employment rate (percent of employ- } \\
\text { ees from the total population) }\end{array}$ & 2011 & Economic & $42.96 \%$ \\
\hline 2 & $\begin{array}{l}\text { Population dynamics (\%) } \\
\text { Dynamics in the number of housing } \\
\text { units (\%) }\end{array}$ & $2005-2011$ & Demographic & $22.63 \%$ \\
\hline 4 & Number of teachers (\%) & 2011 & Social & $15.19 \%$ \\
\hline
\end{tabular}

In order to compute the index, each of the four indicators was normalized, a value between 1 and 5 being given to each LAU 2 unit for each indicator according to their position in the regional hierarchy (quantile breaks), as seen in Fig. 5. The lower the index, the worse is the situation in a LAU 2 unit.

The deprived area index underlines the intraregional disparities that exist between the south and the north of Romania's South West Region. Consequently, while the two northern counties, Vâlcea and Gorj, do not have any LAU 2 units contained in a deprived area, in Mehedinți county 34 LAU 2 units are in a deprived area (51\%), in Dolj county 69 units $(62 \%)$ and in Olt 47 LAU 2 units (42\%). While the county capitals can often be found in the upper $20 \%$ variation of the deprived area index, the same cannot be said about the smaller cities in the region. In fact, two cities, Vânju Mare and Băilesti, are included in deprived areas, with the latter registering a high value of the index, but being surrounded by communes with lower values. All in all, profound rural areas have registered lower values of the index, underlining their socio-economic issues, including lack of proper public services and technical infrastructure. However, rural areas polarized by cities with a low degree of development are also included in deprived areas at regional level, as it is the case of the communes located near Corabia, Drăgănești-Olt, Scornicești (Olt county), Bechet, Dăbuleni, Segarcea (Dolj county) or Strehaia (Mehedinți county).

In the end, 13 deprived areas were identified in the South West region, with their delimitation being realized according to their geographical position, including the existence of neighbouring cities. Table 4 synthesizes this output and compares it with the results of previous studies (Fig. 7). 


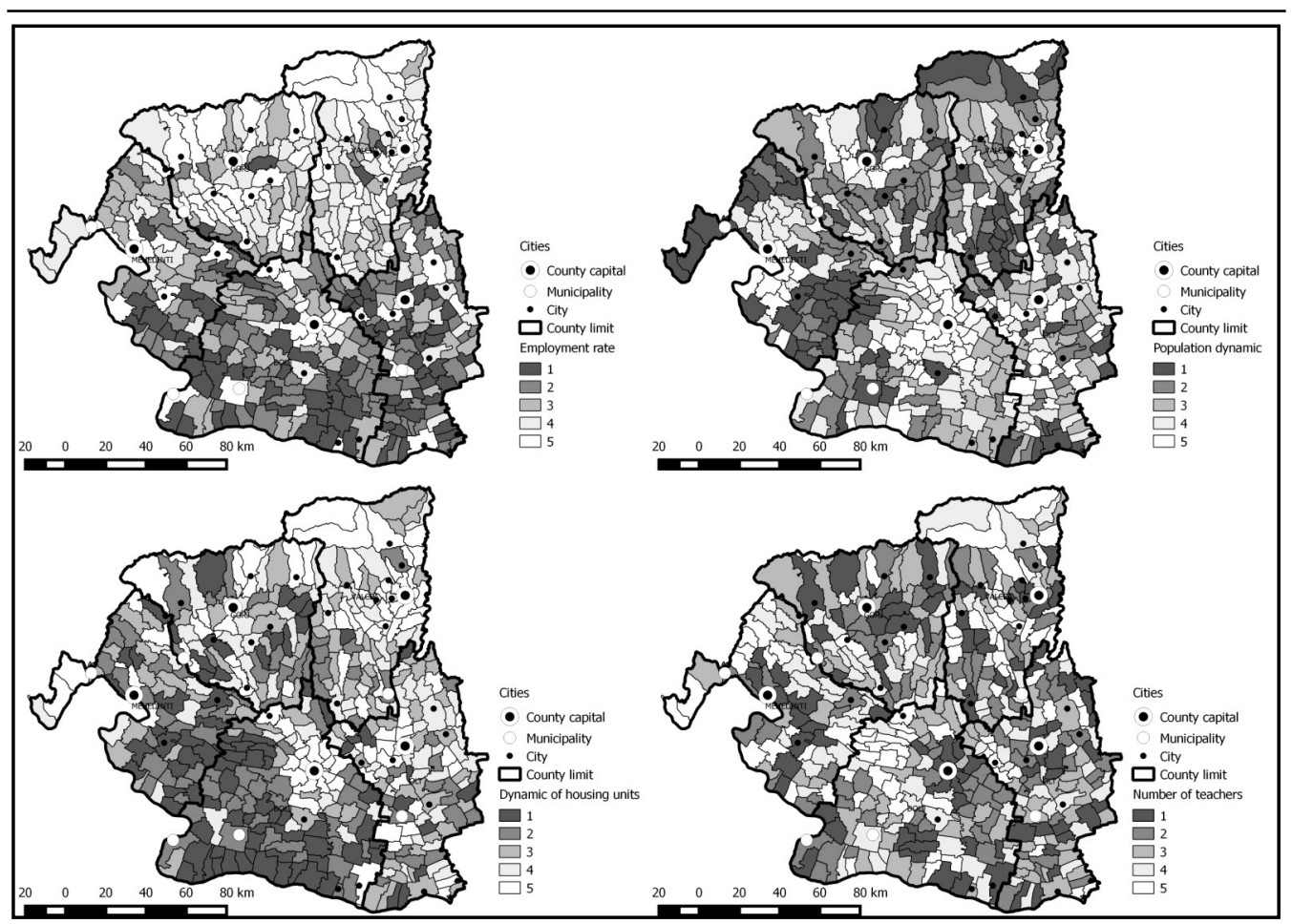

Fig. 5 - Normalization of the four selected indicators

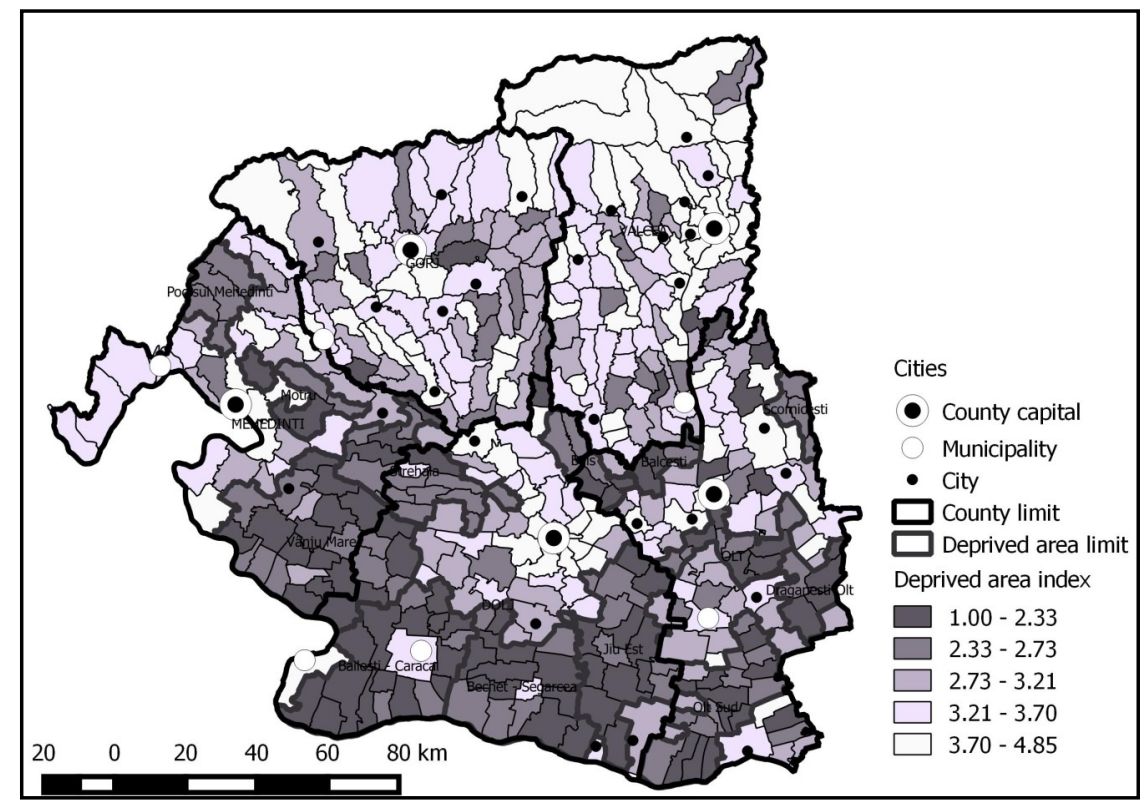

Fig. 6- Deprived area index - Romania's South West Oltenia Region 
Deprived areas - Romania's South West Region

\begin{tabular}{|c|c|c|c|c|c|c|}
\hline No. & Name & Counties & $\begin{array}{l}\text { LAU } 2 \\
\text { units }\end{array}$ & $\begin{array}{l}\text { Deprived } \\
\text { communes }\end{array}$ & $\begin{array}{c}\text { Under- } \\
\text { developed } \\
\text { communes }\end{array}$ & $\begin{array}{l}\text { Areas with } \\
\text { specific } \\
\text { handicaps }\end{array}$ \\
\hline 1 & $\begin{array}{l}\text { Podișul } \\
\text { Mehedinți }\end{array}$ & Mehedinți & 4 & 3 & 3 & 0 \\
\hline 2 & Motru & Mehedinți & 4 & 2 & 0 & 1 \\
\hline 3 & Strehaia & $\begin{array}{l}\text { Mehedinți, } \\
\text { Dolj }\end{array}$ & 16 & 3 & 9 & 11 \\
\hline 4 & $\begin{array}{l}\text { Vânju } \\
\text { Mare }\end{array}$ & $\begin{array}{l}\text { Mehedinți, } \\
\text { Dolj }\end{array}$ & 27 & 5 & 4 & 1 \\
\hline 5 & $\begin{array}{l}\text { Băilești - } \\
\text { Caracal }\end{array}$ & Dolj & 19 & 0 & 0 & 2 \\
\hline 6 & $\begin{array}{l}\text { Bechet - } \\
\text { Segarcea }\end{array}$ & Dolj & 15 & 1 & 0 & 4 \\
\hline 7 & Jiu Est & Dolj & 16 & 0 & 0 & 6 \\
\hline 8 & Olt Sud & Olt & 20 & 0 & 0 & 2 \\
\hline 9 & $\begin{array}{l}\text { Drăgănești } \\
\text { Olt }\end{array}$ & Olt & 5 & 0 & 3 & 0 \\
\hline 10 & $\begin{array}{l}\text { Slatina } \\
\text { Sud }\end{array}$ & Olt & 10 & 0 & 0 & 0 \\
\hline 11 & Scornicești & Olt & 4 & 0 & 2 & 0 \\
\hline 12 & $\begin{array}{l}\text { Bălcessti } \\
\text { (Olt Nord) }\end{array}$ & Olt & 4 & 0 & 0 & 0 \\
\hline 13 & Balș & Olt, Dolj & 6 & 0 & 0 & 0 \\
\hline \multicolumn{3}{|c|}{ TOTAL } & 150 & 14 & 21 & 27 \\
\hline
\end{tabular}

These outputs mean that almost a third of the region's territory can be considered as part of a deprived area. When comparing these results with other studies, 14 of the LAU 2 units individualised in this study also appear in the 2004 poverty map of Romania $(45 \%$ of the deprived communes defined in that study), 21 are also included as communes with a Social Development Index of under 30 (50\% of the under-developed communes determined by that study) and 27 are also part of a less-favoured area $(57 \%$ of the communes defined as areas with specific handicaps). The differences can be explained by the fact that each of the abovementioned studies had a different aim and methodology, with this study focusing on a broader typology of indicators. Furthermore, this research has a strong inter-communal element that other studies did not have, with the exception of the definition of less-favoured areas with special handicaps. Its aim is to identify deprived areas containing at least four contiguous LAU 2 units, with more isolated communes thus being excluded from this delimitation.

The index of deprived areas, comprised of economic indicators (employment rate), demographic indicators (population dynamics - illustrating population decline, but also the dynamics in the number of housing units, which can partly explain the physical development of certain LAU 2 units) and social indicators (number of teachers - an indicator strongly related to the provision of educational services), can be viewed not only as a measure of territorial disparities. It can also be considered a measure of the strength of urban-rural relations at local level, with the under-developed cities with IDSL under 65 (Sandu 2011) characterized by a less visible spill-over effect in the neighbouring communes compared to the values of the index registered in the communes around larger cities as Craiova or Râmnicu Vâlcea, for example. 


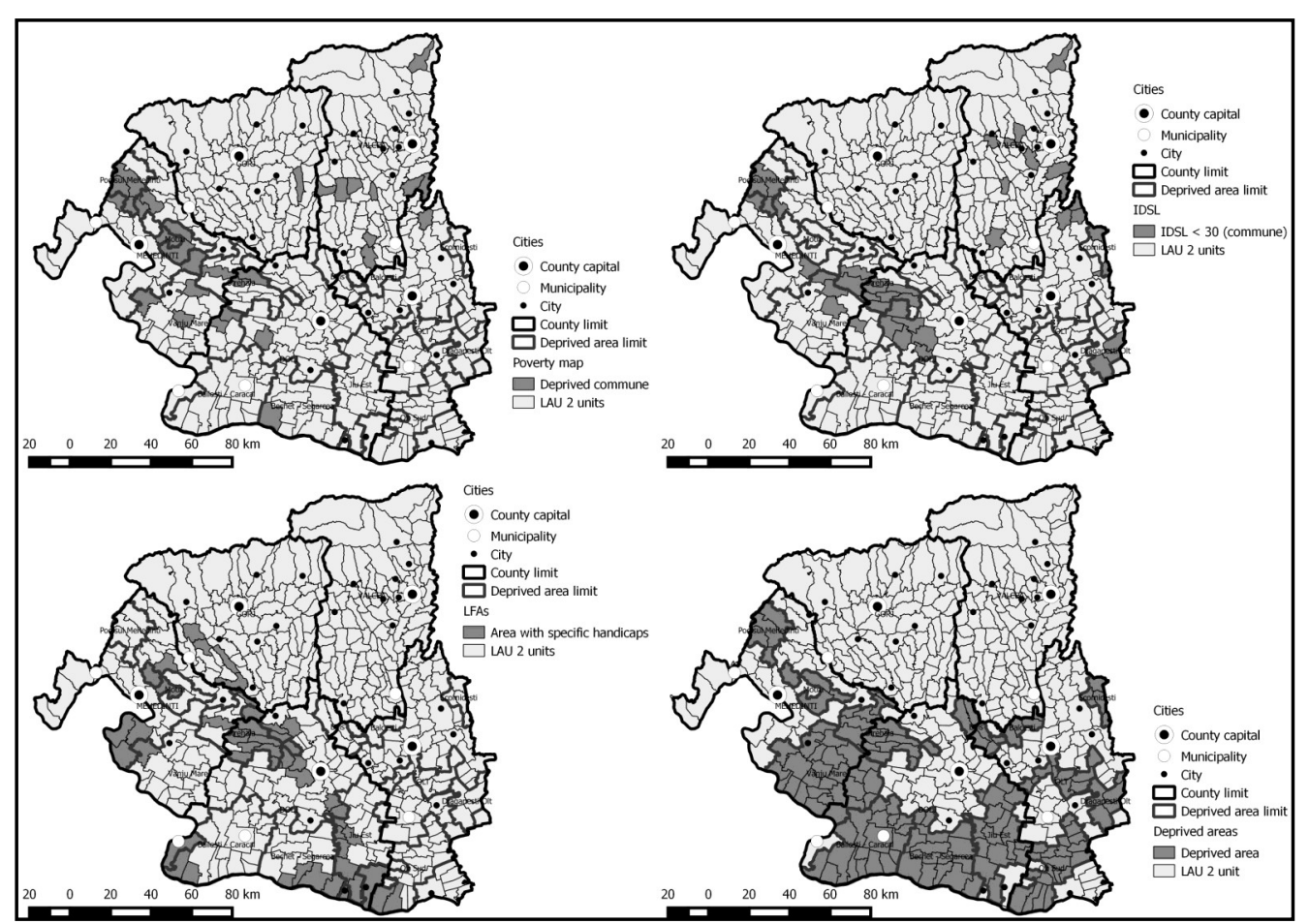

Fig. 7 - Comparing the results with previous studies and legal provisions

While this research focused mainly on indicators related to social and economic dysfunctions, territorial disparities should also be analyzed from the point of view of the environmental quality in an area (Zuindeau 2007, Ancuta et al. 2015). As a result, environmental problems related to socio-economic polarization or imbalances in the distribution of natural resources can greatly contribute to territorial disparities (Ferrara et al. 2014). Land quality issues and their reflection on the well-being of population (Salvati and Zitti 2007) are just one of the complex environmental problems which can deepen territorial disparities at intraregional level. Consequently, it is necessary to include environmental quality as a factor in the analysis of territorial disparities in order to achieve positive results in the sustainable development of these areas (Zuindeau 2007, Ancuta et al. 2015). Moreover, the interventions aimed at reducing territorial disparities and encouraging growth run the risk of causing significant environmental impacts in disadvantaged and ecologically-fragile areas (Salvati and Zitti 2011), thus causing other social and economic problems in the target area.

\section{Conclusions}

Deprived areas should be the subject of territorial policies, as in the case of less-favoured areas supported through the CAP's second pillar. The fact that these areas are lagging behind also represents a motivation for identifying specific measures that can aid in their development, under the umbrella of cohesion policy. Consequently, the individualisation of deprived areas could lead to solutions for the treatment of the territories that have a high risk of becoming territorial poverty pockets (lanoș et al. 2010).

While rural development is often seen as a basic condition for narrowing regional disparities (Dachin 2008), the projects financed in these areas in the last programming period have only partly aided the development process. Tourism is often seen as a key to the positive future of 
deprived rural regions, however the results so far point mostly towards a need to moderate the general optimism regarding the role of tourism in development (Ribeiro and Marques 2002). As far as the development of rural tourism in Romania is concerned, there are restrictive factors such as poor infrastructure, low living standard and lack of proper training of householders (Mazilu and Bădiță 2014) which need to be addressed so that a development strategy based on tourism could be successful. Consequently, interventions in deprived areas must be made only after a thorough analysis of the areas' dysfunctions and potential and should target the narrowing of intraregional disparities by encouraging endogenous development. There are no universal solutions to these problems, which is why an area-based approach realized at intercommunal level, for each deprived area, can have a better chance of success.

The differences between the results of this paper and the results of previous studies reveal the need to standardize the analysis models based on empirically-based results according to the specific regional or national policies proposed for implementation in the defined areas of intervention. A special focus on the methodology used for defining deprived areas can also help in the identification of policy target variables, including early-warning indicators which describe the evolution of different factors (Salvati and Zitti 2011).

In this regard, the inclusion of environmental quality factors can greatly enhance an analysis of deprived areas, as it can underline complex problems related to land degradation or land use change which have an important impact on the quality of life. While the urbanization and high revenue of areas, such as the Motru-Rovinari lignite basin, have caused the registration of a relatively high score in the deprived area index, it is clear that the profound environmental degradation in this territory (Braghină et al. 2008) will represent an important limitative factor in the future development of the area. All in all, the analysis of deprived areas at regional level should be linked to the analysis of restrictive environments, in order to have a clear vision on the territorial disparities involved and to design strategic plans with adequate measures of intervention.

\section{References}

ANCUŢA C. (2010), Territorial Disparities in the Romanian Banat: Assessment, Dynamics and Impact on the Territorial System, Journal of Urban and Regional Analysis 2 (2), 45-62.

ANCUTTA C., OLARU M., POPA N., IȘFĂNESCU IVAN R., JIGORIA-OPREA L. (2015), Evaluation of the sustainable development of rural settlements. Case study: rural settlements from Romanian Banat, Carpathian Journal of Earth and Environmental Sciences 10 (3), 67-80.

BENEDEK J., KURKÓ I. (2011), Evolution and Characteristics of Territorial Economic Disparities in Romania, Theory Methodology Practice 7, 5-15.

BRAGHINĂ C., DRĂGHICI C., PEPTENATU D., PINTILII R. (2008), Rural changes in restructuring mining areas within Gorj county, The Annals of Valahia University of Târgoviște, Geographical Series 8, 151-158.

COMMISSION OF THE EUROPEAN COMMUNITIES (CEC) (2003), Structural Policies and European Territories: Competitiveness, Sustainable Development and Cohesion in Europe - From Lisbon to Gothenburg, Office for Official Publications of the European Communities, Luxembourg.

COMMISSION OF THE EUROPEAN COMMUNITIES (CEC) (2008), Green Paper on Territorial Cohesion. Turning territorial diversity into strength, Brussels, Retrieved from: www.eur-lex.europa.eu.

CONSTANTINESCU I. P. (2012), Shrinking Cities in Romania: Former Mining Cities in Valea Jiului, Built Environment 38 (2), 214-228.

COSTAICHE G. M., NICULAE I. (2014), Sustainable development in public health in the South Muntenia region and South West Oltenia region, Scientific Papers. Series Management, 
Economic Engineering in Agriculture and Rural Development 14 (1), 67-70.

DACHIN A. (2008), Rural Development - A Basic Condition For Narrowing Regional Disparities In Romania, Romanian Journal of Regional Science 2 (2), 106-117.

DAVOUDI S. (2005), Understanding territorial cohesion, Planning Practice \& Research 20 (4), 433-441.

DÉMURGER S. (2001), Infrastructure development and economic growth: an explanation for regional disparities in China? Journal of Comparative Economics 29 (1), 95-117.

DUMITRESCU B. (2008), Oraşele monoindustriale din România: între industrializare forţată şi declin economic, Editura Universitară, Bucureşti.

DWYER J., WARD N., LOWE P., BALDOCK D. (2007), European rural development under the Common Agricultural Policy's 'Second Pillar': institutional conservatism and innovation, Regional Studies 41 (7), 873-887.

ERDELI G., CUCU V. (2007), România: Populaţie. Aşezări umane. Economie, Editura Transversal, Bucureşti.

ESPON (2006), The Role of Small and Medium-sized Towns (SMESTO), ESPON, Luxembourg.

EZCURRA R., RODRÍGUEZ-POSE A. (2014), Government quality and spatial inequality: a cross-country analysis, Environment and Planning A 46 (7), 1732-1753.

FALUDI A. (2004), Territorial cohesion: old (French) wine in new bottles? Urban Studies $41(7), 1349-1365$.

FAN S., HAZELL P. (2000), Should developing countries invest more in less-favoured areas? An empirical analysis of rural India, Economic and Political Weekly 35 (17), 1455-1463.

FERRARA A., SALVATI L., SABBI A., COLANTONI A. (2014), Soil resources, land cover changes and rural areas: towards a spatial mismatch? The Science of the total environment 478, 116-122.

FRASER E. D. G., STRINGER L. C. (2009), Explaining agricultural collapse: macro-forces, micro-crises and the emergence of land use vulnerability in southern Romania, Global Environmental Change 19 (1), 45-53.

GIESECKE J., HORRIDGE M., ZAWALINSKA K. (2010), The Regional Economic Consequences of Less Favoured Area Support: A Spatial General Equilibrium Analysis of the Polish LFA Program, General Paper no. G-211, Retrieved from: www.copsmodels.com.

GORTON M., HUBBARD D., HUBBARD L. (2009), The folly of European Union policy transfer: why the Common Agricultural Policy (CAP) does not fit Central and Eastern Europe, Regional Studies 43 (10), 1305-1317.

GOSCHIN Z., CONSTANTIN D.-L., ROMAN M., ILEANU B. (2008), The current state and dynamics of regional disparities in Romania, Romanian Journal of Regional Science 2 (2), 80-105.

GOVERNMENTAL ORDER no. 24/1998 regarding the status of deprived areas, Retrieved from: www.cdep.ro (in Romanian).

GOVERNMENTAL ORDER no. 525/1999 for the approval of the methodological norms of application of Government Order no. 24.1998 regarding the status of deprived areas, Retrieved from: www.cdep.ro (in Romanian).

HUGGINS R., IZUSHI H., PROKOP D., THOMPSON P. (2014), Regional competitiveness, economic growth and stages of development, Zb. Rad. Ekon. Fak. Rij. 32 (2), 255-283. Bucuresti.

IANOŞ I., HELLER W. (2006), Spaţiu, economie şi sisteme de aşezări, Editura Tehnică,

IANOŞ I., ZAMFIR D., PEPTENATU D., PINTILII R. D. (2009), The individualisation of discontinuities in deeply disadvantaged areas of Romania, Romanian Review of Regional Geography 5 (2), 3-10.

IANOŞ I., PEPTENATU D., PINTILII R.-D., ZAMFIR D. (2010), The insertion of highly disadvantaged areas in regional environments, Analele Universitătii din Oradea - Seria Geografie 20 (2), 159-166. 
IANOŞ I., PETRIŞOR A.-I., ZAMFIR D., CERCLEUX A.-L., STOICA I.-V., TĂLÂNGĂ C. (2013), In search of a relevant index measuring territorial disparities in a transition country. Romania as a case study, DIE ERDE - Journal of the Geographical Society of Berlin 144 (1), 69-81.

INSTITUTE FOR EUROPEAN ENVIRONMENTAL POLICY (IEEP) (2006), An Evaluation of the Less Favoured Area Measure in the 25 Member States of the European Union, Retrieved from: www.ieep.eu.

LAW no. 20/1999 for the approval of the Governmental Order no. 24/1998 regarding the status of deprived areas, Retrieved from: www.cdep.ro (in Romanian).

LAW no. 507/2004 regarding the regulation of financial measures, Retrieved from: www.cdep.ro (in Romanian).

MAZILU M., BĂDIȚA A. (2014), Certainties and Uncertainties in the Development of a Rural Tourism Destination. The Case of Oltenia Region, Romania, Journal of Settlements and Spatial Planning 3, 71-80.

MEDEIROS E. (2012), Territorial Cohesion: a conceptual analysis, 1-36, Retrieved from: www.regionalstudies.org.

MINISTRY OF AGRICULTURE AND RURAL DEVELOPMENT (MARD) (2010), National Rural Development Programme 2007-2013, Retrieved from: www.madr.ro.

NAGY E. (2014), Factorial Analysis of Territorial Disparities on the Hungarian-Romanian Border Region, Romanian Review of Regional Studies 10 (1), 7-14.

NECULA R., NECULA D. (2012), The analysis of the evolution of agriculture in the south west region of Romania, Scientific Papers Series - Management, Economic Engineering in Agriculture and Rural Development 12 (1), 165-168.

NIEBUHR A., STILLER S. (2003), Territorial disparities in Europe, Intereconomics 38 (3), 156-164.

PETRIȘOR A.-I. (2015), Land Cover and Land Use Changes Reflecting the Environmental Impacts of Local Declining Economies. Case-study: South West Development Region. Romania, Revue Roumaine de Géographie 59 (1), 29-39.

POP L. (coord). (2004), Harta sărăciei în România - Metodologia utilizată şi prezentarea rezultatelor, University of Bucharest \& the National Institute of Statistics, Bucharest.

PRĂVĂLIE R., SîRODOEV I., PEPTENATU D. (2014), Detecting climate change effects on forest ecosystems in Southwestern Romania using Landsat TM NDVI data, Journal of Geographical Sciences 24 (5), 815-832.

RIBEIRO M., MARQUES C. (2002), Rural tourism and the development of less favoured areas-between rhetoric and practice, International Journal of Tourism Research 4 (3), 211-220.

RUBEN R., PENDER J. (2004), Rural diversity and heterogeneity in less-favoured areas: the quest for policy targeting, Food Policy 29 (4), 303-320.

RUBEN R., PENDER J., KUYVENHOVEN A. (eds.) (2007), Sustainable Poverty Reduction in Less-favoured Areas: Problems, Options and Strategies, CABI, Oxfordshire.

SALVATI L., ZITTI M. (2007), Territorial disparities, natural resource distribution, and land degradation: a case study in southern Europe, GeoJournal 70 (2), 185-194.

SALVATI L., ZITTI M. (2011), Economic growth vs. land quality: a multidimensional approach in Italy, Journal of Environmental Planning and Management 54 (6), 733-748.

SANDU D., VOINEAGU V., PANDURU F. (2009), Dezvoltarea comunelor din România, National Institute of Statistics \& University of Bucharest, Retrieved from: www.sites.google.com/site/dumitrusandu.

SANDU D. (2011), Social Disparities in the Regional Development and Policies of Romania, International Review of Social Research 1 (1), 1-30.

SĂGEATĂ R. (2011), The administrative - political function of human settlements and the role it plays in organizing geographical space. Case study - Romania, Human Geographies 5 (1), 77-94.

SHUCKSMITH M., CAMERON S., MERRIDEW T., PICHLER F. (2009), Urban-rural 


\section{Radu-Matei COCHECI}

differences in quality of life across the European Union, Regional Studies 43 (10), 1275-1289.

ZUINDEAU B. (2007), Territorial equity and sustainable development, Environmental Values $16(2), 253-268$.

Initial submission: 30.09 .2015

Revised submission: 30.11 .2015

Final acceptance: 04.12.2015

Correspondence: "Simion Mehedinți" Doctoral School, Faculty of Geography, University of Bucharest, 1 Nicolae Balcescu Blv., 010041, Sector 1, Bucharest, Romania

E-mail: matei.cocheci@gmail.com 